\title{
28 Research Square \\ Current Status In Kedir City Towards 90-90-90 Unaids Target (A Case study of Pesantren 1 Health Center)
}

Geofrey Ssekalembe ( $\sim$ gsekalembe@gmail.com )

The University of Manchester Faculty of Biology Medicine and Health

Muhammad Atoillah Isfandiari

Universtas Airlangga Faculty of Public Health

Research article

Keywords: AIDS, ART, HIV, Suppression, Viral, Pesantran, Kediri

Posted Date: September 27th, 2019

DOI: https://doi.org/10.21203/rs.2.15289/v1

License: (c) (i) This work is licensed under a Creative Commons Attribution 4.0 International License.

Read Full License 


\section{Abstract}

Introduction In 2016, UN Member States committed to reduce new HIV infections to fewer than 500,000 annually by 2020 , a $75 \%$ reduction compared with 2010, reduce AIDS-related deaths to fewer than 500 000 globally as a means of ending AIDS by 2030 . The main UNAIDS 2020 target is to ensure that $90 \%$ of the people living with HIV know their status, $90 \%$ of the people living with HIV (who know their HIV status as positive) are already on ART treatment, $90 \%$ of people on treatment are virally suppressed. The objective of the study is to determine the current situation towards the 2020 90-9-90 UNAIDS target and the factors associated with HIV viral load suppression at Pesantren 1 Health center

Method The study was a cross sectional study at Pesantren 1 Health Center in Kediri city. The researcher collected secondary data at from the January 2018 till May 2019, carried in depth interviews, then determined the percentage of HIV positive patients that did a HIV test and received their results as Positive, the percentage of HIV positive patients that started ART treatment, the percentage of HIV positive patients that have viral load suppression from the viral load tests done. The researcher used the chi square analysis to determine the significant factors that may determine viral suppression that are already on ART treatment and then applied the binary logistic regression to determine the significant factors that determine viral suppression among the HIV positive patients that are already on ART treatment.

Results The progress towards the $90-90-90$ UNAIDS target was at $2.4 \%, 93.4 \%, 20.5 \%$. The time taken by the HIV positive patient to start ART treatment from the time of confirmation of HIV positive and the time taken to take the first viral load test from the time when this patient started ART treatment were significantly influencing Viral load suppression.

Conclusion There is need to scale up HIV case-detection capacity through creating awareness about HIV, HIV testing and counselling (HTC), reducing stigma and discrimination and also need to expand of the ART services so as to achieve the 90-0-90 UNAIDS target.

\section{Introduction}

HIV still remains a major public health threat with over 35 million deaths and counting, and in 2016, there were still over two million infections (Unaids, 2016c). However HIV treatment can dramatically extend the lifespan of people living with HIV and effectively prevent HIV transmission (UNAIDS, 2014). In 2016, United Nations Member States committed to reducing new HIV infections to fewer than 500,000 annually by 2020, a $75 \%$ reduction compared with 2010, reduce AIDS-related deaths to fewer than 500000 globally, eliminate HIV-related stigma and discrimination and ending AIDS as a public health threat by 2030 (Unaids, 2016a; WHO, 2016b). The discovery of effective treatment with antiretroviral therapy (ART) in 1996 and subsequent evidence regarding the prevention of illness, death and transmission transformed the epidemic from an unending, unmitigated disaster into something that could be prevented and even ended (Das M, Chu PL, Santos GMi, Scheer S, Vittinghoff E, 2010). One of the 2030 sustainable Development Goals (SDGs) is to achieve the 95-95-95 HIV treatment and having less than 200,000 new HIV infections (UNAIDS, 2015). However, the main 2020 target for UNAIDS is to ensure that $90 \%$ of the people living with HIV know their status, $90 \%$ of the people living with HIV (who know their HIV status as positive) are already on ART treatment, $90 \%$ of people on treatment are virally 
suppressed (UNAIDS, 2017). Attaining this target would mean that, by 2020, 73\% of all people living with HIV will have suppressed viral loads (UNAIDS, 2016). Data from 146 countries show that some have achieved declines in new HIV infections among adults of 50\% or more over the last 10 years, while many others have not made measurable progress, and yet others have experienced worrying increases in new HIV infections (Unaids, 2016b). Asia and the Pacific is expected to experience almost 480,000 new HIV infections in 2030 if coverage remains at 2013 levels, compared to fewer than 97,000 infections under the 90-90-90 Fast-Track response (UNAIDS, 2014).

In 2015, of the 36.7 million people living with HIV globally, an estimated $60 \%$ knew their HIV status, $46 \%$ were on antiretroviral therapy, and 38\% had achieved viral suppression (Unaids, 2016b). In 2015, more than 14.5 million of the 36.7 million (43\%) people living with HIV do not know their HIV status. About $54 \%$ of the people living with HIV have not yet started Antiretroviral treatment and only an estimated 38\% of people living with HIV worldwide are virally suppressed (Unaids, 2016b). Of late, globally, there 37.9 million people having HIV by 2018 and 23.3 million where already accessing ART treatment (62\%) (UNAIDS, 2019a). In the Asia and the pacific region, 5.9 million were estimated to be having HIV of which 3.2 million where accessing ART treatment by 2018 (UNAIDS, 2019a). In 2017, East Java (Jawa Timur) had the highest number of HIV cases in Indonesia (Kementerian Kesehatan RI, 2018b).

By 2018, about 8.1 million people did not know that they were living with HIV (UNAIDS, 2019a). In 2018, 79\% of people living with HIV knew their status. Among people who knew their status, $78 \%$ were accessing treatment. And among people accessing treatment, 86\% were virally suppressed. (UNAIDS, 2019a). Of all people living with HIV, 79\% knew their status, 62\% were accessing treatment and 53\% were virally suppressed in 2018 (UNAIDS, 2019a). For the first time in 2017, the number of people living with HIV accessing treatment exceeded the number of people not yet $\mathrm{n}$ treatment (UNAIDS, 2019b).

Indonesia being among the thirty-five countries accounting for more than $90 \%$ of the people becoming newly infected with HIV have been designated Fast-Track countries, it requires intensive action to mitigate the epidemic (WHO, 2016b). In the Asia and the Pacific region, 5 million people were living with HIV in 2014, 90\% were in six countries: China, India, Indonesia, Myanmar, Thailand and Viet Nam. Women account for a growing proportion of new HIV infections, up from 17\% in 1990 to 34\% in 2014 (Unaids, 2016c). China, India and Indonesia account for $78 \%$ of people newly infected with HIV in the region. These three countries, plus Pakistan and Vietnam, are among the UNAIDS FastTrack countries (Unaids, 2016c). The number of people with HIV/AIDS at the age of $\geq 15$ in Indonesia was estimated and projected to reach 628,492 people in 2017, with the number of new infections as many as 46,357 people and mortality of 40,468 people (Estimation and Projection of HIV/AIDS in Indonesia for the period of 2015-2020, Ministry of Health RI) (Kementerian Kesehatan RI, 2018a). Surabaya and Jakarta are among the cities that account for 1.1 million people living with HIV (Unaids, 2016c).

The preventative effect of antiretroviral therapy has been limited because $40 \%$ of people living with HIV do not know their HIV status and 62\% of people living with HIV are not virally suppressed well shy of the 90-90-90 target. In other words, nearly two thirds of people living with HIV could transmit the virus unless they are provided with prevention tools and empowered to use them (Unaids, 2016b). The likelihood of transmitting HIV from a person living with HIV who is on antiretroviral therapy (ART) and has achieved a suppressed HIV viral load in his/her blood for at least six months is extremely low (negligible) (Del Romero J, Castilla J, Hernando V, Rodríguez C, 2010; Globerman J, Gogolishvili D, 2017) (Centers for Disease Control and Prevention, 2016).

The ASEAN zero project Declaration Initiative has Indonesia as the leading country to ensure zero new HIV Infection, zero Discrimination, and zero deaths related to AIDS in all ASEAN cities 'was adopted by ASEAN Leaders at the 19th Summit on November 17, 2011 in Bali, Indonesia (Kementerian Kesehatan RI, 2015). In Asia 
and the pacific, HIV exists more in the Key populations. HIV cascade data among key populations in Indonesia show very poor rates of retention in treatment and viral suppression (Januraga PP, Reekie J, Mulyani T, Lestari BW, Iskandar S, Wisaksana R, 2018). Site and individual characteristics associated with initiating and continuing treatment suggest an urgent need to develop and implement effective interventions to support patients in achieving viral suppression among all people with HIV (Januraga PP, Reekie J, Mulyani T, Lestari BW, Iskandar S, Wisaksana R, 2018).

The continued expansion of ART and support for sustainable viral suppression will make it possible to significantly reduce transmission and eliminate HIV in the general public (Del Romero J, Castilla J, Hernando V, Rodríguez C, 2010; Arkell C, 2018; Centers for Disease Control and Prevention, 2018; Granich R, Gupta S, Wollmers M, Ruffner M, 2018). In PLHIV, viral load (expressed as HIV RNA copies/mL of blood) is a direct indicator of viral replication (Bvochora T, Satyanarayana S, Takarinda KC, Bara H, Chonzi P, Komtenza B, Clemence D, 2019). Viral load tests prevent patients being unnecessarily switched to more expensive medicines or left to continue on ineffective therapy that can lead to drug resistance and ultimately death (UNAIDS, 2016). World Health Organization (WHO) recommends viral load testing to be the preferred monitoring tool for diagnosing and confirming antiretroviral therapy failure (WHO, 2013, 2016a).

Recent studies have shown that a number of factors influence viral load suppression among HIV positive patients. Amon them include age, sex, marital status, level of education, Level of employment, Entry point, Tuberculosis status, Duration on ART, ART regimen, adherence, first viral load result (Rangarajan S, Colby DJ, Le Truong G, Duc Duong B, Nguyen HH, Plui Broh T, Tran TD, Ngoc BCT, Duc Anh N, Nguyen BTH, Vu Tuyet ND, 2016; Etoori D, Ciglenecki I, Ndlangamandla M, Edwards CG, Jobanputra K, Pasipamire M, Maphalala G, Yang C, Zabsonre I, Kabore SM, Goiri J, Teck R, 2018; Bvochora T, Satyanarayana S, Takarinda KC, Bara H, Chonzi P, Komtenza B, Clemence D, 2019) (Huerga H, Van C, BF, Jihane P, Adrian B and W, Lubbe D, Linda M, David E, Tom E, 2018).

Strong adherence to antiretroviral therapy suppresses viral load to undetectable levels within people living with $\mathrm{HIV}$, greatly reducing the risk of transmitting the virus to others (Das M, Chu PL, Santos GMi, Scheer S, Vittinghoff E, 2010; Saravanan et al., 2016; Globerman J, Gogolishvili D, 2017). Timely initiation of treatment and sustained engagement in HIV care are important to achieving viral load suppression, which is a key marker for successful treatment (Public Health Agency of Canada, 2016) (O'Connor J, Smith C, Lampe FC, Johnson MA, Chadwick DR, Nelson M, Dunn D, Winston A, Post FA, Sabin C, 2017). Since Tb is the leading cause of death among people living of AIDS, All people living with TB should have access to HIV testing and antiretroviral therapy (UNAIDS, 2019b).

As we come closer to 2020, there was need to assess the progress of Pesantren 1 health center towards the UNAIDS 90-90-90 target. The aim of the study was to analyze the progress of the UNAIDS 90-90-90 target, that 90\% of the people living with HIV know their status, $90 \%$ of the people living with HIV (who know their HIV status as positive) are already on ART treatment, $90 \%$ of people on treatment are virally suppressed in Kediri city, a case study of Pesantran 1 health center. It also analyzed the factors that determine viral load suppression among HIV patients that are on care at Pesantren 1 health center.

\section{Methods Of Study}

The study was a cross sectional analytic (Quantitative) study at Pesantran 1 Health Center, Kediri city. The researcher selected Pesentran 1 Health Center from Kediri city because it has the largest number of HIV patients in Kediri city. The population of study included all HIV patients at Pesentran 1 Health center and the 
HIV patients that are on ART treatment and have taken atleast one Viral load test were selected for further analysis of the factors associated with Viral load suppression at Pesantren 1 Health center.

\section{Data collection}

The researcher collected secondary data at the health center from the year 2018 till May 2019, and also carried in depth interviews on two key informants; the Health worker that works on HIV patients in the HIV unit at Pesantren 1 health center, a member of the Peer Support Group in Kediri city to determine the reasons behind the results/findings.

The researcher collected the total number of patients that have visited the number of HIV positive patients that have visited the health center, total number of patients that were referred to the HIV unit to do a HIV test, total number of patients that actually did the HIV test and received their results, total number of patients that started ART treatment, total number of patients that have at least one successful viral load test. The researcher then determined the percentage of HIV positive patients that did a HIV test and received their results as Positive, the percentage of HIV positive patients that started ART treatment, the percentage of HIV positive patients that have viral load suppression from the viral load tests done. Viral load suppression was recorded if there are less than 40 copies of the virus per $\mathrm{ml}$ (Arkell C, 2018). Patients that were referred to the HIV unit to take a HIV test were always first assessed by the health workers in the various units in the health center to have risk factors of a patient who might have HIV. These factors included Tuberculosis, Diarrhea, syphilis, Gonorrhea and other sexually transmitted infections (STIs).

\section{Data analysis}

The researcher analyzed the descriptive statistics of all the HIV positive patients that are on ART treatment at the health center. The demographics analyzed included; Age, sex, Marital status, level of education, Level of employment, Entry point, Tuberculosis status, Years of ART initiation, adherence, follow up status (Death, Lost, transfer out, followed up, due for follow up, active), Viral load test, Viral load result. A viral load test measures the number of HIV viral particles per millilitre of blood (UNAIDS, 2016).

The researcher analyzed using the bivariate analysis to determine the significant factors that may determine viral suppression among the HIV positive patients that are already on ART treatment. The factors analyzed include: Gender, Marital status, level of education, level of employment, risk factor, time taken to take the first load test, Tuberculosis status, time taken to start ART treatment from the time of confirmation of HIV positive, Adherence, regiment (First line, second line or third line), WHO clinical status. However in determining relationship of the independent factors to influence viral load suppression, the researcher restricted the analysis to those who had at least one viral load testing. The researcher used a Pearson chi square analysis for determining the significance of the relationship of the: Gender, Marital status, level of education, level of employment, risk factor staus, Tuberculosis status, Adherence, ART regimen (First line, second line or third line), WHO clinical status to viral load suppression, change in body weight while on ART and one way ANOVA to determine the significance of the relationship of Age, time taken to start ART treatment from the time of confirmation of HIV positive and time taken to take the first load test to achieve viral load suppression. Then, later a binary logistic regression was run for the significant variables to determine how they influence viral load suppression.

Data was analyzed in Microsoft Excel and Stata 14.2.

Results 
The progress of Pesantran 1 health center towards the 90-90-90 UNAIDS target in 2020 is summarized in Table 1 and Figure 1 below.

Table 1: Towards the 90-90-90 UNAIDS Target

\begin{tabular}{|l|c|c|c|c|c|c|}
\hline & \multicolumn{2}{|c|}{2018} & \multicolumn{2}{c|}{2019} & \multicolumn{2}{c|}{ ALL } \\
\cline { 2 - 7 } & $\mathrm{N}$ & $\%$ & $\mathrm{~N}$ & $\%$ & $\mathrm{~N}$ & $\%$ \\
\hline Patient visited the health center & 51,211 & & 16,674 & & 67,885 & \\
\hline Patients referred to the HIV Unit for HIV testing & 807 & $1.7 \%$ & 307 & $2.0 \%$ & 1,114 & $1.8 \%$ \\
\hline Patients tested at the HIV Unit & 606 & $2.3 \%$ & 213 & $2.8 \%$ & 819 & $2.4 \%$ \\
\hline Patients confirmed Positive at the HIV Unit & 14 & & 6 & & 20 & \\
\hline HIV positive patients enrolled on HIV care & 40 & & 13 & & 136 & \\
\hline HIV positive patients enrolled on Pre ART & 5 & & - & & 9 & \\
\hline HIV positive patients enrolled on ART & 35 & $87.5 \%$ & 13 & $100 \%$ & 127 & $93.4 \%$ \\
\hline ART patients that have had a viral load test & - & - & - & - & 29 & $22.8 \%$ \\
\hline ART patients that have had suppressed VL results & - & - & - & - & 26 & $20.5 \%$ \\
\hline
\end{tabular}

Figure 1 shows that $2.4 \%$ of the total number of patients that were counselled and tested from January 2018 till May 2019 were HIV positive. Of the 136 patients that are on HIV care at the health center, 93.4\% have already started ART treatment. Of the 127 HIV positive patients that are on ART treatment, only 20.5\% have suppressed viral loads.

Figure 1: The Progress towards 90-90-90 UNAIDS target

A univariate analysis was done on all the potential variables that could determine viral load suppression among HIV positive patients. Frequencies were determined for categorical variables (Table 1) and summary statistics were determined for the continuous variables. Out of the 136 HIV positive patients on ART treatment, only 29 patients had taken at least one viral load test of which 29 HIV patients had successful viral load results.

A bivariate analysis for the categorical variables were done using the Pearson chi square analysis and the results (Table 1) were to have no significant $(\mathrm{P}>0.05)$ relationship to determine viral load suppression in the HIV positive patients. ANOVA results for the continuous variables (Table 2) indicated that age and body weights while on Pre ART and ART of the HIV positive patient were not significant $(P>0.05)$ to determine viral load suppression.

Table 2: Descriptive statistics of categorical independent variables and Pearson chi square relationship versus viral load suppression 


\begin{tabular}{|c|c|c|c|c|c|}
\hline \multirow{2}{*}{$\begin{array}{c}\text { Independent variables / } \\
\text { Demographics }\end{array}$} & \multirow{2}{*}{$\begin{array}{c}\text { Frequency } \\
\mathrm{N}(\%)\end{array}$} & \multicolumn{2}{|c|}{ Viral load suppression } & \multicolumn{2}{|c|}{ Relationship } \\
\hline & & $\begin{array}{l}\text { Suppressed } \\
\text { (26) }\end{array}$ & $\begin{array}{c}\text { Non suppressed } \\
\text { (3) }\end{array}$ & $\begin{array}{c}\text { Pearson } \\
\text { Chi2 }\end{array}$ & $\begin{array}{c}P \\
\text { value }\end{array}$ \\
\hline \multicolumn{4}{|l|}{ Marital status } & \multirow[t]{4}{*}{1.5058} & \multirow[t]{4}{*}{0.471} \\
\hline Married & $31(22.8)$ & 5 & 0 & & \\
\hline Single & $93(68.4)$ & 17 & 3 & & \\
\hline Window/Widower & $12(8.8)$ & 4 & 0 & & \\
\hline \multicolumn{4}{|l|}{ Gender } & \multirow[t]{3}{*}{0.6971} & \multirow[t]{3}{*}{0.404} \\
\hline Male & $115(84.6)$ & 21 & 3 & & \\
\hline Female & $21(15.4)$ & 5 & 0 & & \\
\hline \multicolumn{4}{|l|}{ HIV Entry point } & \multirow[t]{8}{*}{6.409} & \multirow[t]{8}{*}{0.171} \\
\hline Maternal and Child health & $3(2.2)$ & 0 & 0 & & \\
\hline Out patient & $38(27.9)$ & 8 & 0 & & \\
\hline In patient & $10(7.4)$ & 5 & 0 & & \\
\hline $\begin{array}{l}\text { Key populations (MSM, IDU, sex } \\
\text { workers) }\end{array}$ & 48 (35.3) & 5 & 2 & & \\
\hline NGOs & $21(15.4)$ & 6 & 0 & & \\
\hline self-referral & $11(8.1)$ & 2 & 1 & & \\
\hline Others & $5(3.7)$ & 0 & 0 & & \\
\hline \multicolumn{4}{|l|}{ Level of education } & \multirow[t]{6}{*}{0.5046} & \multirow[t]{6}{*}{0.918} \\
\hline No education & $1(0.7)$ & 0 & 0 & & \\
\hline Primary (SD) & $10(7.4)$ & 1 & 0 & & \\
\hline Junior school (SMP) & $20(14.7)$ & 1 & 0 & & \\
\hline High school (SMA) & $81(59.6)$ & 19 & 2 & & \\
\hline College / University & $24(17.7)$ & 5 & 1 & & \\
\hline \multicolumn{4}{|l|}{ Employment status } & \multirow[t]{3}{*}{0.1195} & \multirow[t]{3}{*}{0.73} \\
\hline Not working & $19(14.0)$ & 1 & 0 & & \\
\hline Working & $117(86.0)$ & 25 & 3 & & \\
\hline \multicolumn{4}{|l|}{ Sexual orientation } & \multirow[t]{5}{*}{1.5058} & \multirow[t]{5}{*}{0.681} \\
\hline Heterosexual & $40(29.4)$ & 6 & 0 & & \\
\hline Homosexual & $89(65.4)$ & 17 & 3 & & \\
\hline Bisexual & $4(2.9)$ & 1 & 0 & & \\
\hline Others & $3(2.2)$ & 2 & 0 & & \\
\hline \multicolumn{4}{|c|}{ Tuberculosis (TB) status during ART } & - & \\
\hline Pulmonary TB & $4(2.9)$ & 1 & 0 & & \\
\hline Extra Pulmonary TB & $3(2.2)$ & 0 & 0 & & \\
\hline Negative (No TB) & $129(94.9)$ & 25 & 3 & & \\
\hline First line ART Regimen & & & & 2.1197 & 0.714 \\
\hline $\mathrm{TDF}(300)+3 \mathrm{TC}(150)+\mathrm{EFV}(600)$ & $48(37.8)$ & 15 & 1 & & \\
\hline $\mathrm{TDF}(300)+3 \mathrm{TC}(150)+\mathrm{NVP}(200)$ & $1(0.8)$ & 0 & 0 & & \\
\hline $\mathrm{TDF}(300)+3 \mathrm{TC}(300)+\mathrm{EFV}(600)$ & $7(5.5)$ & 1 & 0 & & \\
\hline $\mathrm{TDF}(300)+\mathrm{FTC}(200)+\mathrm{EFV}(600)$ & $1(0.8)$ & 0 & 0 & & \\
\hline TDF(300)/3TC(300)/EFV(600) & $35(27.6)$ & 2 & 0 & & \\
\hline $\mathrm{ZDV}(100)+3 \mathrm{TC}(150)+\mathrm{EFV}(200)$ & $1(0.8)$ & 0 & 0 & & \\
\hline $\mathrm{ZDV}(100)+3 \mathrm{TC}(150)+\mathrm{NVP}(200)$ & $4(3.2)$ & 1 & 0 & & \\
\hline $\mathrm{ZDV}(300)+3 \mathrm{TC}(150)+\mathrm{EFV}(600)$ & $1(0.8)$ & 0 & 0 & & \\
\hline $\mathrm{ZDV}(300)+3 \mathrm{TC}(150)+\mathrm{NVP}(200)$ & $25(19.7)$ & 7 & 2 & & \\
\hline $\mathrm{ZDV}(300) / 3 \mathrm{TC}(150)+\mathrm{EFV}(600)$ & $1(0.8)$ & 0 & 0 & & \\
\hline
\end{tabular}




\begin{tabular}{|c|c|c|c|c|c|}
\hline $\mathrm{ZDV}(300) / 3 \mathrm{TC}(150)+\mathrm{NVP}(200)$ & $3(2.4)$ & 0 & 0 & & \\
\hline \multicolumn{4}{|l|}{ Second line regimen } & \multirow[t]{6}{*}{4.000} & \multirow[t]{6}{*}{0.135} \\
\hline TDF(300)+3TC(300) + Efa (600) & $1(10.0)$ & 1 & 0 & & \\
\hline $\mathrm{TDF}(300)+3 \mathrm{TC}(150)+\mathrm{EFV}(600)$ & $2(20.0)$ & 0 & 1 & & \\
\hline $\mathrm{TDF}(300)+3 \mathrm{TC}(150)+\mathrm{NVP}(200)$ & $4(40.0)$ & 2 & 0 & & \\
\hline $\mathrm{TDF}(300)+3 \mathrm{TC}(300)+\mathrm{EFV}(600)$ & $2(20.0)$ & 0 & 0 & & \\
\hline $\mathrm{ZDV}(300)+3 \mathrm{tC}(150)+\mathrm{EFV}(600)$ & $1(10.0)$ & 0 & 0 & & \\
\hline \multicolumn{4}{|c|}{ WHO clinical status at the start of ART } & \multirow[t]{5}{*}{0.1787} & \multirow[t]{5}{*}{0.915} \\
\hline Asymptotic & $63(49.6)$ & 12 & 1 & & \\
\hline Mild symptoms & $34(26.8)$ & 7 & 1 & & \\
\hline Moderate symptoms & $25(19.7)$ & 7 & 1 & & \\
\hline AIDS & $5(3.9)$ & 0 & 0 & & \\
\hline \multicolumn{4}{|l|}{ Adherence } & \multirow[t]{3}{*}{-} & \multirow[t]{3}{*}{-} \\
\hline$>95 \%$ & $83(61.0)$ & 7 & 3 & & \\
\hline Not assessed & $53(39.0)$ & - & - & & \\
\hline \multicolumn{4}{|l|}{ Change in Body weight while on ART } & \multirow[t]{4}{*}{3.1231} & \multirow[t]{4}{*}{0.21} \\
\hline No change in body weight & $10(34.5)$ & 10 & 0 & & \\
\hline Decrease in body weight & $4(13.8)$ & 4 & 0 & & \\
\hline Increase in body weight & $15(51.7)$ & 12 & 3 & & \\
\hline
\end{tabular}

However the time taken by the HIV positive patient to start ART treatment from the time of confirmation of HIV positive and the time taken by the HIV positive patient to take the first viral load test from the time when this patient started ART treatment were found to significantly $(\mathrm{P}<0.05)$ influence the viral load suppression in the HIV positive patients. All levels of significance were compared at $95 \%$.

Table 3: summary statistics for continuous variables and ANOVA results of their relationship versus viral load suppression 


\begin{tabular}{|c|c|c|c|c|c|c|c|}
\hline \multicolumn{2}{|c|}{$\begin{array}{c}\text { Independent variables / } \\
\text { Demographics }\end{array}$} & $\begin{array}{l}\text { Age at } \\
\text { first visit } \\
\text { (Years) }\end{array}$ & $\begin{array}{l}\text { Body } \\
\text { weight at } \\
\text { Pre ART } \\
(\mathrm{Kg})\end{array}$ & $\begin{array}{l}\text { Body } \\
\text { weight at } \\
\text { start of Art } \\
(\mathrm{Kg})\end{array}$ & $\begin{array}{l}\text { Current } \\
\text { body } \\
\text { weight } \\
(\mathrm{Kg})\end{array}$ & $\begin{array}{l}\text { Time taken } \\
\text { to start } \\
\text { ART (days) }\end{array}$ & $\begin{array}{l}\text { Time taken to } \\
\text { do a VL test } \\
\text { (Months) }\end{array}$ \\
\hline \multicolumn{2}{|c|}{ Number of observations } & 29 & 29 & 29 & 29 & 29 & 29 \\
\hline \multirow{4}{*}{$\begin{array}{l}\text { Summary } \\
\text { statistics }\end{array}$} & Mean & 30 & 61.8 & 61.1 & 63.0 & 45 & 24 \\
\hline & Median & 29 & 60 & 59 & 64 & 13 & 17 \\
\hline & Smallest & 20 & 38 & 42 & 40 & 0 & 12 \\
\hline & largest & 47 & 42 & 107 & 100 & 771 & 84 \\
\hline \multirow{2}{*}{$\begin{array}{c}\text { Means of } \\
\text { Viral Load } \\
\text { suppression }\end{array}$} & Suppressed & 31 & 97.0 & 61.8 & 63.5 & 49 & 25 \\
\hline & $\begin{array}{c}\text { Non } \\
\text { suppressed }\end{array}$ & 27 & 54.3 & 55.7 & 58.7 & 11 & 15 \\
\hline \multicolumn{2}{|c|}{$\begin{array}{l}\text { Bartlett's test for equal } \\
\text { variances (Chi2) }\end{array}$} & 0.1869 & 2.8106 & 2.3649 & 2.1828 & 7.991 & 6.5829 \\
\hline \multicolumn{2}{|c|}{ Prob > chi2 } & 0.666 & 0.094 & 0.124 & 0.140 & 0.005 & 0.010 \\
\hline
\end{tabular}

A binary logistic regression analysis was done to determine how the time taken by the HIV positive patient to start ART treatment from the time of confirmation of HIV positive and the time taken by the HIV positive patient to take the first viral load test from the time when this patient started ART treatment were influencing viral load suppression in HIV positive patients.

Table 4: Binary logistic regression results

\begin{tabular}{|l|c|c|c|c|c|c|}
\hline Viral Load suppression & Odds Ratio & Std. Err. & $\mathrm{z}$ & $\mathrm{P}>|\mathrm{z}|$ & \multicolumn{2}{|c|}{$[95 \%$ Conf. Interval] } \\
\hline Time to start ART (days) & 0.974 & 0.046 & -0.56 & 0.573 & 0.887 & 1.069 \\
\hline Time to do a VL test (months) & 0.852 & 0.158 & -0.87 & 0.385 & 0.592 & 1.224 \\
\hline Constant & 2.914 & 8.838 & 0.35 & 0.724 & 0.008 & 1112.301 \\
\hline
\end{tabular}

The results showed that the more the time taken by the HIV positive patient to start ART treatment from the time of confirmation of HIV positive, the less likely (Odds ratio $=0.974,<1$ ) the HIV positive patient is likely to have a viral load suppression. They also showed that the more the time taken by the HIV positive patient to take the first viral load test from the time when this patient started ART treatment, the less likely (Odds ratio = $0.852,<1$ ) the HIV positive patient is likely to have a viral load suppression.

\section{Discussion}


There are several factors associated with achieving each of the 90-90-90 targets. Reaching the first target will require efforts to increase the uptake of HIV testing by addressing issues such as tapping much into HIV testing of Key populations, risk perception, accessibility of services, community knowledge and awareness. The health workers only refer a few selected patient that visit the health center for HIV counselling and testing. A patient is referred to have a HIV test if he has signs of Tuberculosis, Diarrhea,Hepatitis, Oral ovagial candidiasis, dermatitis, herpes, toxoplasmosis, wasting syndrome, Pneumocystis Carinii Pneumonia, Leukocytogenic Leukocytogenesis Vasculitis and other sexually transmitted infections such as Syphilis, Gonorrhea, among others. This has limited the number of patients likely have HIV to be tested hence having a percentage that far away from the $90 \%$ target at just only $2.4 \%$ HIV positive patients. Globally, forty per cent of people living with HIV (19 million) are not aware of their HIV-positive status and therefore HIV testing HIV should be encouraged and supported through self-testing and community-based testing so as to reach people in diverse settings outside health facilities, especially key populations and men (WHO, 2016b). The estimate of the second 90-90-90 target is the highest of the three targets. This mainly attributed to the WHO recommendation of Test and Treat approach in that ART should be initiated in all people living with HIV (HIV exposed infants less than 10 years, adolescents between 10 to 19 years, adults above 19 years and pregnant women living with HIV) regardless of their WHO clinical stage and CD4 count (WHO, 2016a), proper administration of ART therapy through the 4S (Start, Substitute, Switch and STOP) ART medicine being free and it takes much ease for both the health center and patients to easily coordinate and start ART treatment. Shifts toward earlier initiation of treatment, simplified and more tolerable regimens, and adherence support interventions like a peer support group have influenced initiation and uptake of ART treatment. This largely contributed to the surpassing the second 90-90-90 target to 93.4\%.However nationally, ART treatment of HIV patients is still very low. For example in 2016, only 32.1\% (69,954 of the 217,631 HIV patients) were receiving still receiving ART therapy (Kementerian Kesehatan RI, 2016) .On starting treatment, many patients remain engaged in HIV care and have follow-up services to monitor the effectiveness of the treatment. However less have taken a viral load test since their initiation on ART treatment. This has been attributed to the fact that viral load testing is not free at this health center. This largely explains why the estimate of the third 90-90-90 target is very low, same as the whole country at large. The cost and complexity of ART treatment and Viral Load testing technologies also limit their availability. Same case in Indonesia, viral load tests in a few selected central laboratories (UNAIDS, 2016). I also explains more why no patient has more than one viral load result The nearest viral load testing place is located in Surabaya at DR. Soetomo Hospital which is far away from Kediri city making it more costly to do the viral load test. It may also be attributed to the fact that most HIV patients feel healthy and do not feel like doing a viral load test as reported by one of the members of the peer support group in this region. Achieving the 2020 UNAIDS 90-90-90 targets will require a viral load-informed care to ensure optimal HIV clinical follow-up, adherence and resistance monitoring (Bain LE, Nkoke C, 2017). However as earlier noted in earlier studies, data on viral load suppression is not readily available in most provinces in Indonesia making it hard to assess the progress of ART treatment (Ministry of Health Republic Indonesia, 2017). According to (Granich R, Gupta S, Wollmers M, Ruffner M, 2018), an increase in the number of people diagnosed and placed on treatment will normalize HIV epidemic and also encourage others to seek testing and treatment hence achieving the UNAIDS 90-90-90 target. As suggested by (Paudel T, Singh N, Banjara MR, Kafle SP, Ghimire YC, 2016), there is need to scale up HIV case-detection 
capacity through creating awareness about HIV, HIV testing and counselling (HTC), reducing stigma and discrimination and also need to expand of the ART services so as to achieve the 90-0-90 UNAIDS target.

On analyzing the factors that determine viral load suppression among HIV positive patients that are already on ART treatment and have at least taken one viral load test, the time taken by the HIV positive patient to start ART treatment from the time of confirmation being HIV positive and the time taken by the HIV positive patient to take the first viral load test from the time when this patient started ART treatment were found to significantly influence viral load suppression in HIV positive patients.

The time taken by the HIV positive patient to start ART treatment from the time of confirmation being HIV positive and the time taken by the HIV positive patient to take the first viral load test from the time when this patient started ART treatment was found to significantly influence viral load suppression in HIV positive patients and was consistent with previous studies like (Hoenigl M, Chaillon A, Moore D, Morris SR, Mehta SR, Gianella S, Amico KR, 2016). We observed that the average time of time taken to start ART treatment from the time of confirmation of HIV positive status was 45 days (one and a half months). WHO recommends immediate initiation (Test and Treat) of all confirmed HIV positive patients on ART treatment (WHO, 2015b, 2016a). The earlier the better. Early initiation to ART treatment after confirmation of HIV positive improves morbidity and mortality in all stages of HIV infection (Sellers CJ, 2014; Batavia AS, Secours R, Espinosa P, Juste MAJ, Severe P, Pape JW, 2016; Hoenigl M, Chaillon A, 2016; Centers for Disease Control and Prevention, 2018). Early initiation to ART treatment reduces HIV transmission since it reduces the plasma HIV levels (Donnell D, Baeten JM, Kiarie J, Thomas KK, Stevens W, Cohen CR, Mcintyre J, Lingappa JR, 2010).

The time taken by the HIV positive patient to take the first viral load test from the time when this patient started ART treatment was found to significantly influence viral load suppression in HIV positive patients. We observed the patients on ART treatment and have at least one viral load test took an average of 24 months to their first viral load test. WHO recommends viral load monitoring 6 months after initiating antiretroviral therapy and thereafter 12 months annually for people who are virally suppressed (WHO, 2015a, 2016a). There is need to scale up Viral load testing to assess regimen response as a way to improve the substitution, switching to second and third regimens or no change in ART regimen (Awungafa G, Amin ET, Fualefac A, Takah NF, Agyingi LA, Nwobegahay J, Ondoa P, 2018). In people for whom viral load tests suggest treatment failure, WHO recommends enhanced adherence counselling, followed by an additional viral load test to establish re-suppression or to confirm treatment failure and a switch to an alternative regimen (WHO, 2015a). This all sums up the need to do timely viral load testing so as to determine the treatment response, alternative treatment options.

It is also important to note that only 10 out of the 29 patients were assessed for adherence of which 7 patients had viral load suppression, only one patient out of four was on ART had Tuberculosis (Pulmonary TB) and was virally suppressed.

However, social conditions related to poverty, limited viral load testing points, lack of access to support services can decrease the degree to which individuals remain engaged in care. Issues related to privacy and stigma may also impede access to and retention in care. Therefore, it is critical to continue to work towards creating supportive environments that address social determinants, decrease stigma and discrimination, and reduce barriers to prevention, treatment, care and support. It is still worrying that achieving the 909090 by 2020 targets will still leave $27 \%$ of people living with HIV with unsuppressed viral loads in 2020, so expanded 
investments in proven HIV prevention strategies will be critical to hopes for ending the AIDS epidemic (UNAIDS, 2014).

The major strength of this study was that it was the first study to determine progress towards the 2020 90-90-90 UNAIDS target and also conclude that the time taken by the HIV positive patient to start ART treatment from the time of confirmation of HIV positive and the time taken by the HIV positive patient to take the first viral load test from the time when this patient started ART treatment were significant factors to influence viral load suppression among HIV positive patients. The other strength was use of routine programme data that is always updated over time with information collected about all patients who were on ART at this health center without any exclusion. We collected data from the main e-database called System Informasi HIV AIDS (SIHA) which is the first/ primary source of information on all HIV patients used across all the health centers and hospitals in Indonesia. These primary records are routinely audited by the Ministry of Health (Dinas Kesehatan) for its accuracy and consistency. Therefore, we strongly believe that the data collected in our study reflects what is happening in reality at this health center.

The main challenge / limitation in the study was that it was difficult to determine the total number of patients that had ever visited the hospital, the total number of patients that have ever been referred to the HIV unit to HIV counseling and testing, the total number of patients that have ever tested for HIV at the HIV unit. The other limitation was that the study methodology involved analysis of only secondary data of patient records in the SIHA database, and hence our analysis and interpretation of the data are limited to only those variables that are routinely collected from patients/care givers and captured in the patient records. Some of the important variables like height Medium Upper Arm circumference (MUAC) of the patient, HIV status of the other serodiscordant couples and so on, which could have played a major role in determining how other factors like Body Mass Index, Malnutrition influence viral load suppression in the HIV patients.

\section{Conclusions}

Pesentran 1 Health center is still far below the first and third 90 targets though outperforming the second 90 target. The most important target still remains the first target where the health center should identify all the possible people living with HIV mostly the key populations, have them tested for HIV and HIV positive patients should immediately start on ART treatment as treatment is monitored through vira load testing and doing follow

ups for the lost patients. The fact that the time taken by the HIV positive patient to start ART treatment from the time of confirmation being HIV positive and the time taken by the HIV positive patient to take the first viral load test from the time when this patient started ART treatment were found to significantly influence viral load suppression in HIV positive patients, the HIV Unit at Pesentran 1 health center should observe the recommended WHO and UNAIDS guidelines for HIV treatment so as to meet the 2020 90-90-90 UNAIDS target as well as the 2030 95-95-95 SDG target.

\section{Declarations}

\section{Funding}

The study did not get any financial support 


\section{Ethical issues}

Ethical clearance and permission for the study was obtained from East Java Political and National Unity Agency (Bakesbangpol), Ministry of Health Kediri city in collaboration with Faculty of Public Health Universitas Airlangga.

\section{Conflict of Interest}

We declare no conflict of interest

\section{Acknowledgments}

The researcher would like to acknowledge and thank the two key informants; Mr. Imam Ma'ruf, the Health care provider in the HIV Unit at Pesantren 1 health center and Mr. Wisnu Satria Sejati, a member of the Peer Support Group of PLWHA in Kediri city for the time and their responses shared during the in depth interviews to gather more information about HIV care at the health center and the general conditions for the HIV positive patients. The researcher would also wish to thank Mr. Hendick Suprianto at the Ministry of Health, Kediri city for the coordinating the research team to Pesantren 1 health center to enable collecting the patient data from the System Information on HIV AIDS (SIHA) data base.

\section{References}

Arkell C, H. M. (2018) HIV treatment and an undetectable viral load to prevent HIV transmission FACT. Toronto.

Awungafa G, Amin ET, Fualefac A, Takah NF, Agyingi LA, Nwobegahay J, Ondoa P, N. P. (2018) 'Viral load testing and the use of test results for clinical decision making for hiv treatment in Cameroon: An insight into the clinic-laboratory interface', PLoS ONE, 13(6), pp. 3-7. doi: 10.1371/journal.pone.0198686.

Bain LE, Nkoke C, N. J. (2017) 'UNAIDS 90-90-90 targets to end the AIDS epidemic by 2020 are not realistic: Comment on "Can the UNAIDS 90-90-90 target be achieved? A systematic analysis of national HIV treatment cascades"', BMJ Global Health, 2(2), pp. 2016-2018. doi: 10.1136/bmjgh-2016-000227.

Batavia AS, Secours R, Espinosa P, Juste MAJ, Severe P, Pape JW, F. D. (2016) 'Diagnosis of HIV-Associated oral lesions in relation to early versus delayed antiretroviral therapy: Results from the CIPRA HT001 Trial', PLoS ONE, 11(3), pp. 1-7. doi: 10.1371/journal.pone.0150656.

Bvochora T, Satyanarayana S, Takarinda KC, Bara H, Chonzi P, Komtenza B, Clemence D, A. T. (2019) 'Enhanced adherence counselling and viral load suppression in HIV seropositive patients with an initial high viral load in Harare, Zimbabwe: Operational issues', PLoS ONE, 14(2), pp. 1-13. doi: 10.1371/journal.pone.0211326.

Centers for Disease Control and Prevention (2016) CDC Fact Sheet: Today's HIV/AIDS Epidemic.

Centers for Disease Control and Prevention (2018) Evidence of HIV Treatment and Viral Suppression in Preventing the Sexual Transmission of HIV, Department of Health \& Human Services. doi: 10.1109/PVSC.1993.347107. 
Donnell D, Baeten JM, Kiarie J, Thomas KK, Stevens W, Cohen CR, Mcintyre J, Lingappa JR, C. C. (2010) 'Heterosexual HIV-1 transmission after initiation of antiretroviral therapy: a prospective cohort analysis', Lancet, 375(9731), pp. 2092-2098. doi: 10.1016/S0140-6736(10)60705-2.Heterosexual.

Etoori D, Ciglenecki I, Ndlangamandla M, Edwards CG, Jobanputra K, Pasipamire M, Maphalala G, Yang C, Zabsonre I, Kabore SM, Goiri J, Teck R, K. B. (2018) 'Successes and challenges in optimizing the viral load cascade to improve antiretroviral therapy adherence and rationalize second-line switches in Swaziland', Journal of the International AIDS Society, 21(10), pp. 1-8. doi: 10.1002/jia2.25194.

Globerman J, Gogolishvili D, R. S. (2017) Evidence Review: HIV sexual transmission risk by people with suppressed HIV viral load, OHTN EVIDENCE REVIEW: Toronto.

Granich R, Gupta S, Wollmers M, Ruffner M, W. B. (2018) 'Modeling the HIV Epidemic: Why the 95-95-95 Target and ART Effectiveness Parameters Matter', International Journal of Virology and AIDS, 5(1). doi:

$10.23937 / 2469-567 x / 1510041$.

Hoenigl M, Chaillon A, Moore D, Morris SR, Mehta SR, Gianella S, Amico KR, L. S. (2016) 'Rapid HIV Viral Load Suppression in those Initiating Antiretroviral Therapy at First Visit after HIV Diagnosis', Scientific Reports. Nature Publishing Group, 6(September), pp. 1-5. doi: 10.1038/srep32947.

Hoenigl M, Chaillon A, L. S. (2016) 'CD4/CD8 Cell Ratio in Acute HIV Infection and the Impact of Early Antiretroviral Therapy', Clinical Infectious Diseases, 63(3), pp. 425-426. doi: 10.1093/cid/ciw293.

Huerga H, Van C, G., BF, Jihane P, Adrian B, M. and W, Lubbe D, Linda M, David E, Tom E, J. F. (2018) 'Progress towards the UNAIDS 90-90-90 goals by age and gender in a rural area of KwaZulu-Natal, South Africa: A household-based community cross-sectional survey', BMC Public Health. BMC Public Health, 18(1), pp. 4-11. doi: 10.1186/s12889-018-5208-0.

Januraga PP, Reekie J, Mulyani T, Lestari BW, Iskandar S, Wisaksana R, K. N. et (2018) 'The cascade of HIV care among key populations in Indonesia: a prospective cohort study', The Lancet HIV. Elsevier Ltd, 5(10), pp. e560-e568. doi: 10.1016/S2352-3018(18)30148-6.

Kementerian Kesehatan RI (2015) Laporan Kineja Kementrian Kesehatan Tahun 2015. Jakarta.

Kementerian Kesehatan RI (2016) 'Infodatin - Situasi Penyakit HIV AIDS di Indonesia: Pusat Data dan Informasi Kementerian Kesehatan RI’, (c), pp. 2-6.

Kementerian Kesehatan RI (2018a) Indonesia Health Profile, 2017. Available at: website: http://www.kemkes.go.id.

Kementerian Kesehatan RI (2018b) InfoDatin: Situasi Umum HIV/AIDS dan Tes HIV. Jakarta.

Das M, Chu PL, Santos GMi, Scheer S, Vittinghoff E, C. G. (2010) 'Decreases in Community Viral Load Are Accompanied by Reductions in New HIV Infections in San Francisco', PLoS ONE, 5(6). doi: 10.1371/journal.pone.0011068.

Ministry of Health Republic Indonesia (2017) HIV EPIDEMIOLOGY REVIEW, INDONESIA 2016, Directorate Genaral of Disease Prevention and Control,. Jakarta.

O'Connor J, Smith C, Lampe FC, Johnson MA, Chadwick DR, Nelson M, Dunn D, Winston A, Post FA, Sabin C, P. A. (2017) 'Durability of viral suppression with first-line antiretroviral therapy in patients with HIV in the UK: an 
observational cohort study', The Lancet HIV, 4(7), pp. e295-e302. doi: 10.1016/S2352-3018(17)30053-X.

Paudel T, Singh N, Banjara MR, Kafle SP, Ghimire YC, P. B. (2016) 'Epidemiology of HIV , programmatic progress and gaps in last 10 years in Nepal', Journal of Virus Eradication, 2(Supplement 4), pp. 35-40.

Public Health Agency of Canada (2016) Summary: Measuring Canada's Progress on the 90-90-90 HIV Targets. Canada. Available at: https://www.canada.ca/content/dam/phac-

aspc/documents/services/publications/diseases-conditions/summary-measuring-canada-progress-90-90-90-hivtargets/hiv90-eng.pdf\%0Ahttps://www.canada.ca/content/dam/phac-

aspc/documents/services/publications/diseases-con.

Rangarajan S, Colby DJ, Le Truong G, Duc Duong B, Nguyen HH, Plui Broh T, Tran TD, Ngoc BCT, Duc Anh N, Nguyen BTH, Vu Tuyet ND, E. (2016) 'Factors associated with HIV viral load suppression on antiretroviral therapy in Vietnam', Journal of Virus Eradication, pp. 94-101.

Del Romero J, Castilla J, Hernando V, Rodríguez C, G. S. (2010) ‘Combined antiretroviral treatment and heterosexual transmission of HIV-1: Cross sectional and prospective cohort study', BMJ (Online), 340(7757), p. 1179. doi: 10.1136/bmj.c2205.

Saravanan, S. et al. (2016) 'Community viral load, antiretroviral therapy coverage, and HIV incidence in India: A cross-sectional, comparative evaluation study', HHS Public Access, 3(4), pp. 1-18. doi: 10.1016/S23523018(16) 00019-9.Community.

Sellers CJ, W. DA (2014) 'Antiretroviral therapy: When to start', Infectious Disease Clinics of North America, 28(3), pp. 403-420. doi: 10.1016/j.idc.2014.05.004.

Unaids (2016a) HIV Prevention 2020 Road Map.

Unaids (2016b) HIV PREVENTION GAP REPORT.

Unaids (2016c) UNAIDS 2016-2021 strategy: On the fast-Track to end AIDS.

UNAIDS (2014) Fast-Track: Ending the AIDS Epidermic by 2030. Geneva, Switzerland.

UNAIDS (2015) 'Understanding fast Track; Accelerating Action to End the AIDS epidemic by 2030', Unaids.

UNAIDS (2016) The need for routine viral load testing. Geneva, Switzerland.

UNAIDS (2017) Ending AIDS Progress Towards the 90-90-90 Targets, Global Aids Update. Geneva, Switzerland. doi: UNAIDS/JC2900E.

UNAIDS (2019a) Fact sheet - 2018 GLOBAL HIV STATISTICS 2019. Geneva, Switzerland.

UNAIDS (2019b) Tuberculosis and HIV-Progress towards the 2020 target. Geneva, Switzerland. Available at: http://www.unaids.org/sites/default/files/media_asset/tuberculosis-and-hiv-progress-towards-the-2020target_en.pdf.

WHO (2013) CONSOLIDATED GUIDELINES ON THE USE OF ANTIRETROVIRAL DRUGS FOR TREATING AND PREVENTING HIV INFECTION. Geneva, Switzerland. 
WHO (2015a) Guideline on When to Start Antiretroviral Therapy and on Pre-Exposure Prophylaxis for HIV: Potential Limitations of Earlier Initiation of Therapy. Geneva, Switzerland. Available at: http://www.ncbi.nlm.nih.gov/books/NBK327118/.

WHO (2015b) Guideline on When To Start Antiretroviral Therapy and on Pre-Exposure Prophylaxis for HIV. Geneva, Switzerland.

WHO (2016a) Consolidated Guidelines on The use of Antiretroviral drugs for treating and preventing HIV infection; Recommendations for a Public Health Approach second edition. Geneva, Switzerland.

WHO (2016b) World Health Organization. Progress Report on Prevent HIV,Test and Treat all. Geneva, Switzerland.

\section{Figures}

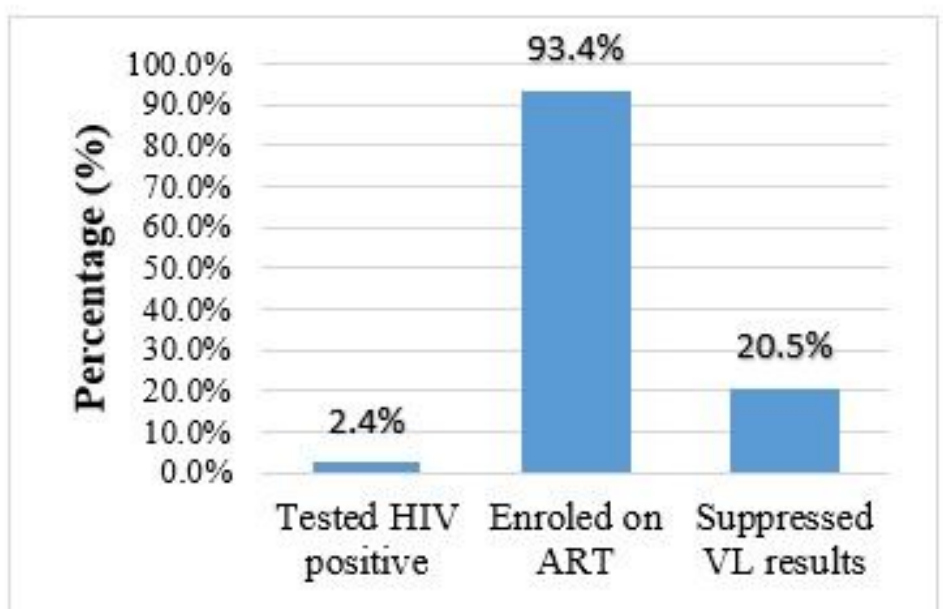

Figure 1: The Progress towards 90-90-90 UNAIDS target

\section{Figure 1}

The Progress towards 90-90-90 UNAIDS target 